\title{
Türkiye'de Para Politikasının Konut Fiyatlarına Etkisi
} \begin{abstract}
Etkisi
\section{Öz}

Çalışmanın amacı Türkiye ekonomisinde para politikası ve konut fiyatları arasındaki ilişkiyi ampirik olarak araştırmaktır. Ampirik analiz yöntemi olarak Yapısal VAR analizi tercih edilmektedir. Çalışmada kullanılan değişkenler; federal fon oranı, sanayi üretim endeksi, yapı kullanım izni, reel konut fiyatları ve gecelik faiz oranıdır. Analiz 2011:12017:12 dönemini kapsamakta ve aylık veriler kullanılmaktadır. Analiz sonuçları, para politikasının konut fiyatları üzerinde etkisi olmadığını göstermektedir. Aynı dönemde, konut fiyatları yalnızca kendi gecikmeli değerlerine önemli düzeyde tepki vermektedir.
\end{abstract}

Anahtar Kelimeler: Konut Fiyatları, Para Politikası, Yapisal VAR
Musa Bayır ${ }^{1}$

The Effect of Monetary Policy on House Prices in the Turkey

\begin{abstract}
The aim of the study is to empirically investigate the relationship between monetary policies and house prices in Turkey's economy. The Structural VAR analysis is preferred as the method of empirical analysis. The variables used in the study are federal funding rate, industrial production index, building use permit, real house prices and overnight interest rate. The analysis includes the periods between 2011:1 and 2017:12 and monthly data is used. The results of the analysis indicate that monetary policy has no effect on house prices. In the same period, the house prices only reacted to the lagged values of the house prices, significantly.
\end{abstract}

Keywords: House Prices, Monetary Policy, Structural VAR

\section{Giriş}

Enflasyon hedeflemesi stratejisinin benimsendiği ekonomik sistemlerde, merkez bankaları kısa vadeli faiz oranları üzerinden piyasa faiz oranları üzerinde etki oluşturmayı amaçlamaktadır. Bu hem doğrudan piyasadaki likidite maliyetlerinin değişmesi hem de ekonomik birimlerin beklenti ve güven düzeyinin etkilenmesi yoluyla ortaya çıkmaktadır. Böylece konut kredisi faizleri, mevduat faizleri, hazine tahvili faizleri gibi piyasa faiz oranları ve para politikasına ilişkin beklentiler üzerinde ortaya çıkan değişimler enflasyon, gelir, varlık fiyatları, döviz kuru gibi makroekonomik değişkenler üzerinde önemli etkiler ortaya çıkarmaktadır.

$A B D$ ekonomisinde konut ve gayrimenkul sektöründe yaşanan gelişmeler ulusal ve uluslararası piyasalarda önemli sıkıntılar oluşturmuştur. 2008 ekonomik krizi öncesinde ve sonrasında yapılan çeşitli teorik ve ampirik çalışmalar, ABD ekonomisinde 2000'li yılların başından itibaren uygulanan genişletici para politikası ve krize yol açan konut balonu arasında sıkı bir ilişki olduğunu göstermiştir. Bununla birlikte Mishkin (2007), para politikasının konut fiyatları üzerindeki etkisinin nasıl, ne düzeyde ve ne şiddette etkilediğinin daha problemli bir husus olduğunu ifade etmiştir. Zira para politikasının konut sektörü dışında ekonominin diğer kesimleri üzerinde istenmeyen sonuçlar ortaya çıkarıp çıkarmadığı oldukça önemlidir. Bu durum çeşitli ülke ekonomilerinde de bu konu üzerine araştırmalar yapılmasının önünü açmıştır. Shi, Jou, ve Tripe (2014) konutun bireylerin varlık portföyündeki oranının bazı

${ }^{1}$ Araş. Gör. Dr., Bandırma Onyedi Eylül Üniversitesi IïBF, İktisat Bölümü, musa.bayir@gmail.com, Yazar ORCID bilgisi: http://orcid.org/0000-0002-6877-4032 
ülkelerde $\% 70$ 'lere kadar çıkabildiğini, dolayısıyla ortaya çıkan enflasyonist etkilerin makroekonomik istikrar üzerinde önemli sorunlar ortaya çıkarabileceğini ifade etmiştir. Bununla birlikte, Kasai ve Gupta (2010) konut fiyatlarının para politikası şoklarına karşı sınırlı bir tepki verdiği sonucuna ulaşmıştır. Sonuç olarak, para politikasının konut fiyatları üzerindeki etkisi ülke ve zaman dilimine göre farklılaştığı için ülke ve zaman bazında değerlendirme yapılması en doğru sonucu vermektedir.

Türkiye ekonomisinde 2001 yılından itibaren enflasyon hedeflemesi stratejisi uygulanmış ve önemli ölçüde başarılı olunmuştur. Bu çerçevede 2008 ekonomik krizi para politikası uygulamalarında nispeten fiyat istikrarsızlığı endişelerinin yaşanmadığı bir döneme rast gelmiştir. Bu dönemde küresel piyasalarda yaşanan panik havası Türkiye ekonomisini de önemli ölçüde etkilemiştir. Fiyat istikrarı konusundaki endişelerin azalması TCMB'ye Türkiye ekonomisi üzerindeki muhtemel olumsuz etkileri en aza indirmeye yönelik bir politika anlayışı benimseme imkânı sağlamıştır (Yılmaz 2009, 4). TCMB'nin bu doğrultuda 2008 yılında 275 baz puan, 2009 yılında 850 baz puanlık bir faiz indirimine gittiği görülmektedir. 2009 yılından itibaren iç ve dış talepteki ayrışmadan kaynaklanan cari açık finansal istikrarı önemli ölçüde tehdit eder hale gelmiştir. Dolayısıyla Merkez bankasının para politikası uygulamalarında finansal istikrarı da hedeflediği görülmektedir. Bu amaçla 2010 yılından itibaren oluşturulan yeni politika tasarımında; faiz koridoru, 1 hafta vadeli repo faizi ve likidite yönetimi, zorunlu karşıııklar gibi politika araçları kullanılmaya başlanmıştır. Politika faizi olarak belirlenen 1 hafta vadeli repo faizi ile günlük fonlama yapma imkânı elde edilmiştir. Bununla birlikte, gecelik borçlanma ve borç alma faiz oranları arasında belirlenen faiz koridoru ile piyasadan gecelik vadede fon fazlasının çekilmesi olanağı elde edilmiştir. Bu araçlara ek olarak likidite yönetiminde zorunlu karşılıklar politikası da aktif bir şekilde ve çeşitlendirilerek kullanılmıştır (Alper ve Tiryaki 2011). Yeni politika tasarımında ara değişken olarak toplam krediler ve döviz kuru belirlenmiştir. Bu durumda varlık fiyatlarının para politikası amaç fonksiyonunda yer almadığı yalnızca toplam talep ve maliyet unsurları ile ilişkileri bağlamında tepki verildiği ifade edilebilmektedir (Kara 2012, 6-10).

Şekil 1-a genel fiyat artışı ve konut fiyat artışı arasındaki ilişkiyi, şekil 1-b konut fiyat artışı ve TCMB fonlama faizi ilişkisini göstermektedir. Şekil 1-a'dan görüldüğü gibi 2011-2017 yılları arasında konut fiyatlarında yıllık ortalama \%13,5 oranında bir artış varken, fiyatlar genel düzeyi yıllık ortalama \%8,7 oranında artmıştır. 2014-15 yılları arasında bu farkın daha da açıldığı ve fiyatlar genel düzeyinde sırasıyla $\% 8,1$ ve $\% 8,8^{\prime}$ lik bir artışa rağmen, konut fiyatlarındaki artışın \%16,1 ve \%18,4 oranında gerçekleştiği görülmektedir. Bu göstergeler konut fiyatları ve fiyatlar genel düzeyi arasında ciddi bir farklılaşma olduğunu göstermektedir. Şekil 1-b panelinde konut fiyatlarındaki artış ve TCMB fonlama faizinin 2011-18 yılları arasındaki durumu görülmektedir. Gelişmiş ülkelerde yaşanan tecrübeler konut fiyatlarında genel fiyat düzeyine oranla yaşanan yüksek artışların para politikasından önemli ölçüde etkilendiğini göstermiştir. Grafikten hareketle TCMB fonlama faizi ve konut fiyatları arasında negatif bir ilişki olduğu görülmektedir. 
Şekil 1: Türkiye Ekonomisinde Faizler ve Konut Fiyat Artışları iliş̧kisi

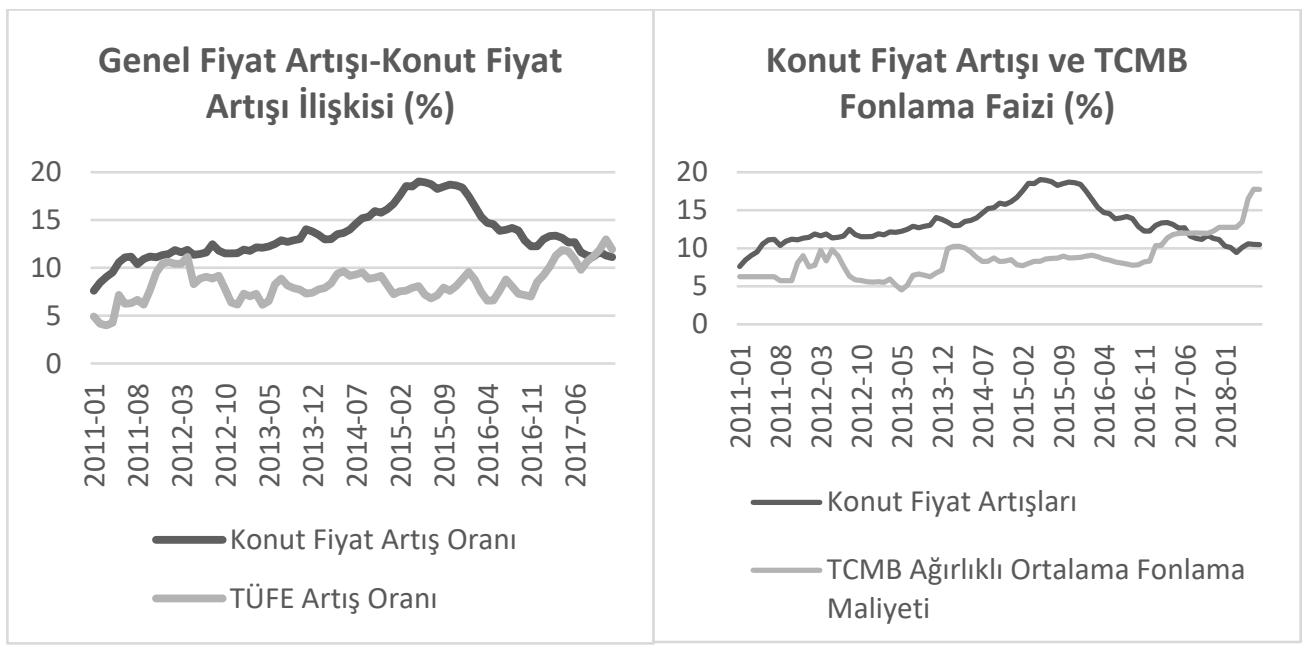

Kaynak: TCMB (2018)

2008 finansal krizinde konut sektöründe yaşanan olumsuzlukların ekonomi üzerinde ortaya çıkardığı etki literatürde oldukça güçlü bir şekilde vurgulanmıştır. Bu çerçevede, Merkez bankalarının uyguladığı para politikasının varlık fiyatları üzerinde, özelde konut ve gayrimenkul sektörü üzerinde oluşturduğu etkilerin iyi incelenmesi gerekmektedir. Böylece önleyici politikaların uygulanması imkânı doğacaktır. Çalışma bu bağlamda Türkiye ekonomisinde konut fiyatları ve para politikası ilişkisini ampirik olarak inceleyerek literatüre katkı sunmayı hedeflemektedir. Bu doğrultuda çalışmanın amacı, dışsal para politikası şoklarının konut fiyatları üzerindeki dinamik etkisini VAR analiziyle araştırmaktır. İkinci bölümde para politikası ve konut fiyatlarına ilişkin teorik ve ampirik çerçeve çizilmektedir. Üçüncü bölümde yöntem ve veri seti tanıtılırken, dördüncü bölümde analiz sonuçlarına yer verilmektedir. Beşinci bölümde ise sonuç ve değerlendirmelere yer verilmektedir.

\section{Para Politikasının Konut Fiyatlarına Etkisi}

Ekonominin çıktı kompozisyonunda yaşanan değişim parasal aktarım mekanizmalarının etkinliği üzerinde de önemli etkiler ortaya çıkarmıştır. Özellikle konut ve yatırım harcamalarının payının artması para politikası uygulamalarında göz önünde bulundurulan değişkenlerin etkisinin yeniden değerlendirilmesine yol açmıştır. Bu bağlamda neo klasik parasal aktarım mekanizmalarına ilk ciddi eleştiriler Bernanke ve Gertler (1995)'den gelmiştir. Bu çalışmada asimetrik bilginin parasal aktarım mekanizmalarındaki rolüne vurgu yapılmıştır. Asimetrik bilginin kredi piyasalarındaki rolünü en aza indirmenin en kesin yolunun kredi kullananların sunacağı teminatlar olduğu ifade edilmiştir. Buradan hareketle, konut sektöründe yaşanan bir canlanmanın konut sahiplerinin teminatlarında ortaya çıkardığı artışla birlikte, parasal genişlemenin ortaya çıkaracağı genişletici etkilerin konut sektöründe diğer sektörlere kıyasla daha güçlü olacağı vurgulanmıştır. Sonraki dönemlerde kendi kendini besleyen bir sürecin ortaya çıkmasının finansal riskleri artıran bir durum ortaya çıkarabileceği ifade edilmiştir. Stock ve Watson (2003) ise, konut fiyatlarının reel sektörde önemli bir öncü gösterge olduğunu ve piyasalar hakkında önemli bilgiler barındırdığını ifade etmiştir. Shiller (2006), para politikasının konut fiyatları üzerinde güçlü bir etki oluşturduğuna ve ABD konut sektöründe fiyat balonu oluştuğuna ilişkin önemli sonuçlara ulaşmıştır. Taylor (2007), Taylor 
kuralı göz önünde bulundurulduğunda FED'in 2003-06 yılları arasında uyguladığı düşük faiz politikasının $A B D$ konut sektöründe ortaya çıkan fiyat balonunun temel nedeni olduğunu ifade etmiştir. Taylor (2007), ABD ekonomisinde 2000 yılında \%6,5 olan politika faiz oranı 2003-04 yıllarında \%1'e düşürüldüğünü ve 2000 'li yılların başında ABD ekonomisinde yaşanan finansal risklerin ortadan kaldırılmasının amaçlandığını ifade etmiştir. Ancak uygulanan genişletici para politikası konut talebini ve konut fiyatlarını artırıc bir etki ortaya çıkarmıştır. Para politikası normalleştirilip faiz oranları normal seviyelerine çekildiğinde ise konut sektöründe sert bir talep daralması ve konut fiyatlarında hızlı bir çöküş yaşandığı ifade edilmiştir. Daha sonraki dönemlerde Jarocinski ve Smets (2008); Leamer (2007) gibi çalışmalar da, ABD ekonomisinde finansal krize neden olan konut balonunun nedeninin FED 'in genişletici para politikası olduğu sonucunu teyit etmekte ve para politikasının konut fiyatları üzerinde önemli sonuçları olabileceğini vurgulamaktadır.

$A B D$ ekonomisinde konut sektöründen kaynaklı yaşanan ekonomik gelişmeler ve konut fiyatları para politikası ilişkisine dair teorik ve ampirik bulgular, literatürde diğer ülkeler açısından gerçekleştirilen teorik ve ampirik çalışmaların da artmasına önemli katkı sağlamıştır. Mishkin (2007), para politikasının konut fiyatları üzerindeki etkisini açıklayan parasal aktarım mekanizmalarını sistematik bir şekilde ortaya koymaktadır. Bu aktarım mekanizmaları; sermayenin kullanım maliyeti kanalı, konut fiyat beklentileri kanalı, firma maliyetleri kanalı, servet etkisi kanalı ve banka kredi kanalı şeklinde sınıflandırılmıştır. İlk aktarım mekanizması olan sermayenin kullanım maliyeti kanalı mortgage oranı kanalı ismiyle Dokko vd. (2009); İslamoğlu ve Buluş (2018); Wadud vd. (2012); Xu ve Chen (2012) gibi ampirik çalışmalarda da vurgulanmıştır. Bu aktarım mekanizmasında, sermayenin kullanım maliyeti konut harcamaları için kullanılacak sermayenin talep edilmesinin belirleyicisi olarak nitelendirilmiştir. Para politikasında yaşanan değişim sermayenin kullanım maliyetini belirleyen en önemli faktör durumundaki faiz oranlarını etkiler ${ }^{2}$. Kısa vadeli faiz oranlarına ilişkin uzun vadeli beklentilerin belirlediği uzun vadeli faiz oranlarında yaşanan değişim ise sermaye varlıklarına yönelik talebi değiştirmektedir. Böylece kullanılan konut kredisi miktarı ve konut talebi etkilenmektedir. İkinci aktarım mekanizmasında konut fiyatlarına ilişkin beklentilerin değişmesinin faiz oranları üzerinden ortaya çıkaracağı etkiler ifade edilmektedir. Para politikasında yaşanan değişimler sermayenin kullanım maliyeti kanalıyla konut talebini etkilemektedir. Bu durum sermayenin kullanım maliyetini belirleyen diğer bir faktör olan konut fiyatlarına ilişkin gelecekteki fiyat beklentilerini etkilemektedir ${ }^{3}$. Söz gelimi konut fiyatlarına ilişkin fiyat beklentilerinin düşmesi sermaye kullanım maliyetini artırmaktadır. Böylece konut talebi düşmektedir. Üçüncü aktarım mekanizması literatürde firma maliyet kanalı olarak isimlendirilip, para politikasının faiz oranları vasıtasıyla konut arzına etkisini göstermektedir. Konut yapımının nispeten kısa sürmesi, konut projesi finansmanlarında kısa vadeli faiz oranlarını etkili duruma getirmektedir. Kısa vadeli faiz oranlarının değişmesi konut yapım maliyetlerini etkilemektedir. Böylece inşa edilen konut sayısı değişmektedir (Mishkin, 2007: 9). Servet etkisi kanalı Anda ve Modigliani

\footnotetext{
2 Sermayenin kullanım maliyeti şu şekilde belirlenmektedir. $u c=p h\left[\left\{(1-t) i-\pi^{e}\right\}-\left\{\pi_{h}^{e}-\pi^{e}\right\}+\delta\right]$ denkleminde; yeni konut sermayesi almanın nispi fiyatını, $i$ mortgage oranını, $\pi_{h}^{e}$ konut fiyatının beklenen değer artışını, $\delta$ konutu kullanmanın ortaya çıkardığı değer kaybını, $t$ vergi oranını, $\pi^{e}$ beklenen enflasyon oranını göstermektedir. Buna göre, $\left\{(1-t) i-\pi^{e}\right\}$ vergi sonrası reel faiz oranını ifade etmektedir. Bu aktarım kanalında faiz oranı sermayenin kullanım maliyetini bu denklem üzerinden etkilemektedir.

${ }^{3}$ Sermayenin kullanım maliyetinin belirlendiği denklemde $\left\{\pi_{h}^{e}-\pi^{e}\right\}$ konut fiyatlarının beklenen reel değer artışını ifade etmektedir. Bu denklemden hareketle konut fiyatlarının artmasına ilişkin beklentiler ve sermayenin kullanım maliyeti arasında negatif bir ilişki söz konusudur.
} 
(1963)'ün tüketim harcamalarını hane halkının hisse senedi, tahvil gibi varlıklarından oluşan ömür boyu geliri ile ilişkilendirdiği görüşe dayanmaktadır. Buna göre genişletici para politikasının konut fiyatlarını artırması kişilerin bireysel konut varlıklarının değerini artırmaktadır. Böylece servet miktarı değişen bireyler konut talebini değiştirmektedir (Boivin vd., 2010: 12; Mishkin, 2007: 9-11; Wadud vd., 2012). Beşinci aktarım mekanizması olan kredi kanalı Bernanke ve Gertler (1995) tarafından literatüre kazandırılmıştır. Merkez bankaları ekonomiye kısa vadeli faiz oranları üzerinden etkide bulunmayı amaçlarken konut ve yatırım harcamaları gibi reel ekonomik değişkenler genelde uzun vadeli faiz oranlarından etkilenmektedir. Bu durum sermayenin kullanım maliyetiyle açıklanan doğrudan faiz kanalının ampirik olarak araştırıldığı çalışmalar tarafından da teyit edilmiştir. Bu durum neo klasik parasal aktarım kanalları reddedilmemekle birlikte onları destekleyici bir takım yeni görüşlerin ortaya konulmasına neden olmuştur. Bunlardan ilki banka kredi kanalı etkileri olarak isimlendirilip doğrudan banka mevduatlarının artmasının kredi miktarında ortaya çıkardığı artışa dayandırılmıştır. Asimetrik bilginin varlığından hareket eden bilanço dengesi kanalında ise, genişletici para politikasının konut fiyatları ve diğer varlıklar üzerinde ortaya çıkaracağı artışın potansiyel daha güçlü teminatlar ortaya çıkaracağı, dolayısıyla mevcut kredi miktarı ve koşullarında genişleme ortaya çıkacağı ifade edilmiştir. Böylece konut piyasalarında bir canlanma ortaya çıkacağı vurgulanmıştır (Bernanke ve Gertler, 1995: 3-4; Boivin vd., 2010: 17-21; Mishkin, 2007: 9-10).

Para politikası ve konut fiyatları arasındaki ilişkinin incelendiği ampirik çalışmalara bakıldığında çoğunlukla VAR analizi yönteminin kullanıldığı görülmektedir. ABD ekonomisinde para politikası ve konut fiyatları ilişkisini inceleyen çalışmalardan Jarocinski ve Smets (2008) Bayezyen VAR analizi kullanarak ABD ekonomisinde 1987-2007 yılları arasında para politikasının konut fiyatları üzerinde önemli bir etkisi olduğunu ve 2008 finansal krizine yol açan konut balonunda uygulanan genişletici para politikasının etkili olduğu sonucuna ulaşılmıştır. McDonald ve Stokes (2013), yapısal VAR yöntemi kullanarak 1987-2011 döneminde $A B D$ ekonomisinde para politikası ve konut fiyatları arasındaki negatif ilişkiyi teyit eden sonuçlar elde etmiştir. Avrupa ekonomisinde para politikası ve konut fiyatları ilişkisini ampirik olarak inceleyen çalışmalara bakıldığında, lacoviello (2002) 6 Avrupa ülkesinde 19731998 yılları arasında kullandığı VAR yöntemiyle, para politikasının konut fiyatları üzerinde önemli bir etkisi olduğu sonucunu elde etmiştir. Giuliodori (2005) 1979-98 yılları arasında 9 Avrupa ülkesinde gerçekleştirdiği yapısal VAR analiziyle, para politikası şoklarının konut fiyatları üzerinde etkili olduğunu bununla birlikte etkinin ülkeye göre farklılaştığı sonucuna ulaşmıştır. Bjørnland ve Jacobsen (2010) 1983-2006 yılları arasında Norveç, İsveç ve İngiltere ekonomisine yönelik bir analiz gerçekleştirmiştir. Gerçekleştirilen yapısal VAR analizi sonuçları, para politikası şoklarının konut fiyatları üzerinde etkili olduğunu, faiz oranlarının konut fiyatı şoklarına tepki verse de bunun büyüklügünün ülke ve zamana göre farklılaştığını göstermiştir. Rosenberg (2018) 1989-2017 dönemi için İsveç, Norveç ve Danimarka ekonomisini yapısal VAR yöntemi ile incelemiştir. Analiz sonuçları, 3 ülkede de genişletici para politikasının konut fiyatları üzerinde pozitif etki oluşturduğunu, geleneksel olmayan para politikasının bu etkiyi artırdığını, ülkeler arasında para politikası rejimleri farklı olmasına rağmen para politikasının konut fiyatları üzerindeki etkisinin olağanüstü bir şekilde farklılaşmadığı sonucuna ulaşılmıştır. Musso vd. (2011) ise 1986-2009 yılları arasında, ABD ve Euro bölgesi ülkelerinde para politikasının konut fiyatları üzerindeki etkisini karşılaştırmıştır. Gerçekleştirilen yapısal VAR analizi sonucunda, para politikası şoklarının konut fiyatlarına etkisi ABD'de Euro bölgesine göre daha sert bulunmuştur. VAR analizi yerine regresyon ve buna bağlı olarak bazı 
istatistiksel testler kullanan Tse vd. (2014) Ingiltere ve Galler ekonomisinde 2001-2013 döneminde para politikasının konut fiyatları üzerinde oldukça etkili olduğu sonucuna ulaşmıştır. VECM modeli kullanan Panagiotidis ve Printzis (2016) ise, Yunanistan ekonomisinde 1997-2013 döneminde, mortgage kredilerinin konut fiyatları üzerinde önemli bir etkisi bulunduğu sonucunu elde etmiştir. Gelişmiş ülkeler arasında yer alan Avustralya ekonomisinde 1974-2008 dönemini yapısal VAR yöntemi ile analiz eden Wadud vd. (2012), konut fiyatlarının temel belirleyicilerinin para politikası ve fiyatlar genel düzeyi olduğu sonucuna ulaşmıştır. Buna ek olarak, para politikasının etkisinin yalnızca konut fiyatlarını artırması şeklinde ortaya çıktığı dolayısıyla daraltıcı para politikasının konut fiyatları üzerinde önemli bir negatif etkisi olmadığı sonucuna ulaşılmıştır. Goodhart ve Hofmann (2008) Panel VAR yöntemi kullanarak 17 gelişmiş ülke ekonomisi için toplu bir analiz gerçekleştirmiştir. Aktarım mekanizmalarından kredi kanalını ön plana çıkaran çalışmada 1970-2006 yıllarında para ve kredi şoklarının konut fiyatları üzerinde oldukça güçlü bir etkiye sahip olduğu, bu etkinin 1985-2006 dönemleri için yapılan analizde daha güçlü bir şekilde ortaya çıktığı görülmüştür. Gelişmekte olan ülke ekonomilerini inceleyen ampirik çalışmalara bakıldığında, Çin ekonomisinde Guo ve Huang (2010) 1997-2008 yıllarında Markov rejimi-anahtarlama modeliyle, Zhang (2013) ise 1998-2013 yılları arasında VAR yöntemi kullanarak para politikası şoklarının konut fiyatları üzerinde etkili olduğu sonucuna ulaşmıştır. Xu ve Chen (2012) regresyon ve Granger nedensellik analizi kullanarak, 1998-2009 yılları arasında genişletici para politikasının konut fiyatlarındaki artışı hızlandırdığı sonucuna ulaşmıştır. Güney Afrika ekonomisine yönelik çalışmalardan Kasai ve Gupta (2010) finansal serbestleşme öncesi ve sonrası para politikası ve konut fiyatları ilişkisine dair çıkarım yapmaktadır. 1967-1983 ve 1983-2006 şeklinde iki dönem için yapısal VAR yöntemiyle gerçekleştirilen analizde, finansal serbestleşmenin para politikasının konut fiyatları üzerindeki etkisini artırdığı bununla birlikte konut fiyatlarının para politikası şoklarına duyarlılığının sınırlı olduğu sonucuna ulaşmıştır. Mutsvunguma (2013) ise, sınırlandırılmış VAR yöntemini kullanarak Güney Afrika'da 19942011 dönemi için para politikası ve konut fiyatları arasında nedensellik ilişkisi bulunduğunu ve konut fiyatlarının para politikası şoklarına anlık tepki verdiğini göstermiştir.

Türkiye ekonomisine yönelik çalışmaların konut sektörüne ilişkin verilerin 2010 yılından itibaren yayımlanmaya başlanması nedeniyle sınırlı kaldığı görülmektedir. Bu çalışmalardan Badurlar (2008), VECM ve nedensellik analizi kullanarak konut fiyatlarının belirleyicilerini 1990-2006 döneminde çeyrek dönemlik verilerle analiz etmiştir. Konut fiyatları göstergesi olarak konut sahipliği değişkeninin kullanıldığı analizde, konut fiyatları ve MB gecelik faiz oranları arasında çift yönlü nedensellik ve uzun dönemde negatif ilişki olduğu sonucuna ulaşılmıştır. Akkas ve Sayılgan (2015), konut fiyatları ve konut kredisi faizleri arasındaki ilişkiyi 2010:1-2015:4 döneminde aylık frekansta nedensellik analiziyle araştırmıştır. Analiz sonuçları konut kredisi faizlerinden konut fiyatlarına doğru nedensellik ilişkisi olduğunu göstermiştir. Karamelikli (2016) 2010:1-2016:2 döneminde aylık frekansta veriler kullanarak konut fiyatlarını etkileyen faktörleri NARDL yöntemiyle analiz etmiştir. Analiz sonuçları, nominal faizler ve konut fiyatları arasında negatif ilişki olduğunu göstermiştir. Kolcu ve Yamak (2018) ise 2010:1-2017:9 döneminde aylık frekansta veriler kullanarak konut fiyatlarını etkileyen faktörleri ARDL yöntemiyle analiz etmiştir. Analiz sonuçları, konut kredisi faizlerinin konut fiyatları üzerinde uzun dönemde etkisiz, kısa dönemde negatif olarak etkili olduğunu göstermiştir. Konut talebini analiz eden çalışmalardan Bekmez ve Özpolat (2013) VAR analiziyle 1986-2009 döneminde faiz oranlarının konut talebini negatif olarak etkilediği sonucuna ulaşmıştır. Öztürk ve Fitöz (2009) regresyon analiziyle 1968-2006 döneminde, Uysal 
ve Yiğit (2016) ise VECM ve nedensellik analiziyle 1970-2015 döneminde faiz oranları ve konut talebi arasında pozitif ilişki olduğu sonucuna ulaşmıştır. İslamoğlu ve Buluş (2018), Johansen eşbütünleşme analizini kullanarak 2007-2017 dönemini çeyrek dönemlik verilerle incelemiştir. Çalışmada, ilk modelde mortgage faiz oranlarındaki değişimin konut fiyatlarını negatif yönde etkilediği, ikinci modelde para politikası uygulamalarında kullanılan kısa vadeli faiz oranlarının mortgage faiz oranları üzerinde pozitif bir etki ortaya çıkardığı sonucuna ulaşılmıştır. Karamelikli (2016), teoriyle uyuşmayan bu sonuçlara ilişkin reel faiz oranlarıyla yapılacak analizin daha kullanışı olacağına dair bir çıkarım yapmaktadır. Darıcı (2018), ARDL yöntemini kullanarak gerçekleştirdiği çalışmada, 2010-2016 dönemini aylık verilerle analiz etmiştir. Analiz sonuçları, genişletici para politikasının konut fiyatlarını pozitif etkilediğini göstermiştir.

\section{Yöntem, Model ve Veri Seti}

\subsection{Yapısal VAR Analizi}

Sims (1980) bütün değişkenlerin içsel olarak kabul edildiği VAR modellerini geliştirmiştir. Burada, bütün değişkenlerin şoklara eş zamanlı tepki verdiği varsayımı söz konusudur. Ekonomi teorisi göz önüne alındığında, böyle bir varsayıma başvurulması analizleri sorunlu hale getirmektedir. Çalışmamızda parasal şokların etkilerinin analiz edildiği düşünüldüğünde, politika şokları bütün değişkenler üzerinde eşzamanlı etki ortaya çıkarmadığı gibi, teorik olarak dışsal bazı değişkenler üzerinde hiçbir etkinin ortaya çıkmaması beklenmektedir (Elbourne, 2008: 76). Sims (1986) ve Bernanke (1986) bu sorunu aşmak için iktisat teorisi ve diğer ön bilgilere dayalı kısıtlardan hareketle oluşturulan yapısal şokların kullandığı yapısal VAR modelini geliştirmiştir.

(1) ve (2) numaralı denklem bir dönem gecikmeli VAR modelini (3) numaralı eşitlik ise denklemin matris formunu göstermektedir.

$$
\begin{aligned}
& X_{t}=b_{10}-b_{12} Z_{t}+\beta_{11} X_{t-1}+\beta_{12} Z_{t-1}+u_{x t} \\
& Z_{t}=b_{20}-b_{21} X_{t}+\beta_{21} X_{t-1}+\beta_{22} Z_{t-1}+u_{z t}
\end{aligned}
$$

Burada, $X_{t}$ ve $Z_{t}$ içsel değişkenleri ifade etmektedir. $u_{x t}$ ve $u_{z t}$ birbirinden bağımsız beyaz gürültü süreçli hata terimlerini göstermektedir. (1) ve (2) numaralı denklem sistemi matris formunda gösterilirse;

$$
\left[\begin{array}{cc}
1 & b_{12} \\
b_{21} & 1
\end{array}\right]\left[\begin{array}{l}
X_{t} \\
Z_{t}
\end{array}\right]=\left[\begin{array}{l}
b_{10} \\
b_{20}
\end{array}\right]+\left[\begin{array}{ll}
\beta_{11} & \beta_{12} \\
\beta_{21} & \beta_{22}
\end{array}\right]\left[\begin{array}{l}
X_{t-1} \\
Z_{t-1}
\end{array}\right]+\left[\begin{array}{l}
u_{x t} \\
u_{z t}
\end{array}\right]
$$

Burada;

$\mathrm{B}=\left[\begin{array}{cc}1 & b_{12} \\ b_{21} & 1\end{array}\right], \mathrm{Y}_{\mathrm{t}}=\left[\begin{array}{l}X_{t} \\ Z_{t}\end{array}\right], \Gamma_{0}=\left[\begin{array}{l}b_{10} \\ b_{20}\end{array}\right], \Gamma_{1}=\left[\begin{array}{ll}\beta_{11} & \beta_{12} \\ \beta_{21} & \beta_{22}\end{array}\right], \mathrm{u}_{\mathrm{t}}=\left[\begin{array}{l}u_{x t} \\ u_{z t}\end{array}\right]$ olmak üzere (1) ve (2) numaralı eşitlik kapalı formda şu şekilde yazılabilir;

$$
\begin{aligned}
& B y_{t}=\Gamma_{0}+\Gamma_{1} Y_{t-1}+u_{t} \\
& y_{t}=B^{-1} \Gamma_{0}+B^{-1} \Gamma_{1} Y_{t-1}+B^{-1} u_{t} \\
& y_{t}=A_{0}+A_{1} Y_{t-1}+\varepsilon_{t}
\end{aligned}
$$

(4) numaralı eşitlikte, B değişkenler arası eşzamanlı ilişki matrisini, $\Gamma_{0}$ sabit terimler matrisini, $\Gamma_{1}$ gecikmeli değişkenlere ilişkin parametre matrisini, $u_{\mathrm{t}}$ yapısal model kalıntılarını 
göstermektedir. $E\left(u_{t}\right)=0$ olmak üzere, $E\left(u_{t} u_{t}^{\top}\right)=\sum u$ pozitif tanımlı beyaz gürültü kovaryans matrisini ifade etmektedir (Pfaff, 2008: 2). (4) numaralı denklemin her iki tarafı $B^{-1}$ ile çarpıldığında ve düzenlendiğinde (6) numaralı eşitlikte (4) numaralı modelin indirgenmiş kalıbı elde edilmektedir. Burada, $\varepsilon_{\mathrm{t}}$ vektörü indirgenmiş kalıbın hata terimleri olup ut'nin doğrusal bileşimini göstermektedir.

Nihai olarak, Indirgenmiş VAR modelinin hata kovaryans matrisi şu şekilde elde edilmektedir.

$$
E\left(\varepsilon_{t} \varepsilon_{t}^{\prime}\right)=\sum_{\varepsilon}=B^{-1} E\left(u_{t} u_{t}^{\prime}\right) B^{-1^{\prime}}
$$

Yapısal VAR analizinde; kısa dönem kovaryans ilişkileri, birikmiş etki tepkilere yönelik uzun dönem kısıtlamaları ve kalıntılar vektöründe yapılacak kısıtlamaları tanımlamak için indirgenmiş VAR formunun tahmininden elde edilen $\sum_{\varepsilon}$ tahminleri kullanılmaktadır. Bununla birlikte, tahmin edilecek eleman sayısının $\sum_{\varepsilon}$ 'nin bağımsız moment sayısını aşmaması gerekmektedir. kxk boyutlu bir matriste $k^{2}$ bilinmeyen eleman olduğu ve $k(k+1) / 2$ bağımsız moment olduğu düşünüldüğünde, modelde $\left(k^{2}-k\right) / 2$ tane kısıt uygulanması gerekmektedir. Özetle, iktisadi teori ve öngörülerden hareketle uygulanacak kısıtlar, yapısal VAR modelinin tanımlanmasını ve tahmin edilmesini sağlamaktadır.

\subsection{Model}

İktisadi teori göz önünde bulundurularak kısıtlamaların uygulandığı ve modelin belirlendiği eşitlik (8)'de yer almaktadır. (8) numaralı eşitlikte $\varepsilon_{t}$ ilgili değişkenlere ait yapısal şokları, $u_{t}$ ise indirgenmiş kalıp hata terimlerini ifade etmektedir.

$$
\left[\begin{array}{c}
\varepsilon_{t}^{i^{y}} \\
\varepsilon_{t}^{Y} \\
\varepsilon_{t}^{Y K} \\
\varepsilon_{t}^{K F} \\
\varepsilon_{t}^{i}
\end{array}\right]=\left[\begin{array}{ccccc}
1 & 0 & 0 & 0 & 0 \\
0 & 1 & 0 & 0 & 0 \\
0 & 0 & 1 & 0 & 0 \\
0 & b_{42} & b_{43} & 1 & b_{45} \\
b_{51} & b_{52} & b_{53} & b_{54} & 1
\end{array}\right]\left[\begin{array}{c}
u_{t}^{i^{y}} \\
u_{t}^{Y} \\
u_{t}^{Y K} \\
u_{t}^{K F} \\
u_{t}^{i}
\end{array}\right]
$$

Eşitliğin sağ tarafında değişkenler arası eşanlı ilişkileri gösteren matris üzerinde yapılacak kısıtlamalar yapısal VAR modelinin belirlenmesini ve tahmin edilmesini sağlamaktadır. Matriste birinci satır ilk değişkenin sırasıyla diğer değişkenlerdeki şoklara verdiği eşanlı tepkiyi, birinci sütun sırasıyla diğer değişkenler üzerinde ortaya çıkardığı eşanlı etkiyi göstermektedir. Buna göre ilk satırda ekonomi üzerindeki dışsal etkileri ifade etmektedir. Burada ekonomi üzerinde etkisi olabilecek dışsal değişken olarak dünya faiz oranı seçilmektedir. Değişken olarak ABD para politikasının göstergesi olan federal fon oranı tercih edilmiştir. Iktisadi teoriden hareketle küçük ülke varsayımıyla dünya faiz oranı ilgili ülkenin ekonomik göstergelerini etkilerken, ilgili ülkedeki gelişmelerden etkilenmemektedir (Kim ve Roubini, 2000: 568). Bununla birlikte modelimizde nominal katılıkların olduğu varsayımından hareketle federal fon oranının eş zamanlı olarak yalnızca parasal göstergeler üzerinde etkili olduğu kabul edilmektedir. İkinci ve üçüncü değişken gelir ve yapı kullanım iznidir. Clarida vd. (2001); Svensson (1998)'in tanımladığı Yeni Keynezyen küçük ekonomi modelinde makroekonomik değişkenler politika değişkenlerine eş zamanlı tepki vermemektedir. Bunun nedeni, piyasalardaki nominal katılıklar (uzun vadeli nominal sözleşmeler, etkin ücret yaklaşımı) ve toplam talebin tüketicilerin portföyündeki yerel varlıklara ilişkin reel getiri beklentisiyle 
ilişkilendirilmesiyle açıklanmaktadır. Bu çerçevede modelimizde para politikasının gelir ve yapı kullanım izni sayısı değişkenleri üzerinde gecikmeli etkide bulunacağı kabul edilmektedir. Sims ve Zha (2006) merkez bankalarının politika tasarımında piyasa verilerini göz önünde bulundurmasıyla ilgili detaylı bir çerçeve sunmaktadır. Geçmiş dönemlerde uygulanacak para politikasında göz önünde bulundurulan piyasa verilerine anlık erişim olmadığı, dolayısıyla merkez bankasının gecikmeli değerleri göz önünde bulundurarak politika tasarımında bulunduğu varsayılmaktadır. Oysa günümüz koşulları göz önünde bulundurulduğunda merkez bankasının birçok veriye günlük olarak ulaştığı ve buna uygun modelleme yapabileceği ifade edilmektedir. Bu çerçevede modelimizde para politikasının bütün değişkenlerden eş zamanlı etkilendiği kabul edilmektedir. Diğer ilişkilere bakıldığında gelirin konut fiyatları üzerinde eşanlı etkide bulunurken, yapı kullanım izni üzerinde gecikmeli etkide bulunduğu kabul edilmektedir (Bjørnland ve Jacobsen, 2010: 221). Çalışmada ayarlama maliyetleri ve planlama gecikmesi nedeniyle reel faaliyetlerin fiyat değişikliklerinden gecikmeli olarak etkilendiği varsayılmaktadır (Kim ve Roubini, 2000: 568). Dolayısıyla yapı kullanım izni konut fiyatları üzerinde eşanlı etkide bulunurken, konut fiyatlarındaki değişim yapı kullanım izni üzerinde gecikmeli etkide bulunmaktadır. Aynı varsayımdan hareketle konut fiyatlarının gelir üzerinde de eşanlı etkide bulunmadı̆̆ kabul edilmektedir.

\subsection{Veri Seti}

Çalışma 2011:1-2017:12 dönemini kapsayıp, analizde aylık veriler kullanılmaktadır. Ampirik analizde kullanılan VAR modeli 5 içsel değişkenden oluşmaktadır. Bu değişkenler; dünya faiz oranı, gelir, alınan yapı kullanım izni sayısı, konut fiyatları ve para politikasıdır. Çalışmada, dünya faiz oranının göstergesi olarak federal fon oranı değişkeni kullanılmaktadır. Bu değişken ABD para politikasının yerine kullanılmakta olup literatürde dünya faiz oranının önemli bir göstergesi kabul edilmektedir. Gelir değişkenine ilişkin aylık frekansta veri bulunmadığı için bu değişkenin göstergesi olarak sanayi üretim endeksi kullanıımıştır. Çalışmada yapı kullanım izni sayısı modele konut arzını temsilen eklenmiştir. Bu değişken alınan yapı kullanım izin (ruhsat) belgesi sayısını göstermektedir. Konut fiyatları göstergesi olarak TÜFE $(2003=100)$ endeksi ile deflate edilmiş reel konut fiyat endeksi tercih edilmiştir. Para politikası göstergesi olarak ise BIST bankalar arası para piyasası gecelik faiz oranı seçilmiştir. Değişkenler, değişkenler için kullanılan semboller ve değişkenlere ilişkin verilerin elde edildiği kaynaklar tablo 1'de gösterilmektedir. Buna göre, federal fon oranı Federal Reserve Bank of St. Louis veri tabanından, sanayi üretim endeksi $(2015=100)$ ve yapı kullanım izni sayısı TÜiK'ten, konut fiyat endeksi $(2010=100)$ ve BIST bankalar arası para piyasası gecelik faiz oranı TCMB veri tabanlarından temin edilmiştir.

Tablo 1: Değişkenler, Değişkenlerin Sembolleri ve Veri Kaynakları

\begin{tabular}{ccc}
\hline Değişken & Sembol & Kaynak \\
\hline Federal Fon Oranı & FFO & Federal Reserve Bank of St. Louis \\
Sanayi Üretim Endeksi & SUE & TÜiK \\
Yapı Kullanım İzni Sayısı & YKi & TÜiK \\
Reel Konut Fiyat Endeksi & RKFE & TCMB \\
BIST Bankalar arası Para Piyasası & FO & TCMB \\
Gecelik Faiz Oranı & & \\
\hline
\end{tabular}

Değişkenlerden sanayi üretim endeksi, yapı kullanım izni sayısı ve reel konut fiyat endeksi logaritmik formda kullanılmıştır. Ayrıca sanayi üretim endeksi değişkeni doğrudan mevsim ve takvim etkilerinden arındııımış olarak temin edilirken, yapı kullanım izni sayısı değişkeninde Tramo/Seats programı kullanarak mevsimsel düzeltme yapılmıştır. 


\section{Ampirik Sonuçlar}

Zaman serisi analizinde kullanılacak verilerin durağan olması çok önemlidir. Durağan olmayan serilerle çalışmak sahte regresyona dolayısıyla geçersiz test sonuçlarının elde edilmesine yol açacaktır. Bu çerçevede ilk olarak analizde kullanılacak serilerin durağanlığını araştırmak için birim kök testleri yapılmaktadır. Birim kök testi olarak literatürde en çok kullanılan birim kök testleri olan Genişletilmiş Dickey Fuller (ADF), Phillips-Perron (PP), Kwiatkowski-Phillips-Schmidt-Shin (KPSS) testleri tercih edilmiştir. Birim kök testleri sabit terim ve sabit terim+trend değişkenin olduğu iki ayrı model için elde edilen tahminler çerçevesinde yapılmıştır. Tablo 2'de yer alan sonuçlara göre; FFO, SUE, değişkenleri her üç birim kök testinde düzey halde birim köke sahip, birinci farkı alındı̆̆ında durağan bulunmuştur. YKi değişkeni ADF ve KPSS birim kök testlerine göre birinci farkı alındığında, PP testine göre ise düzey halde durağan bulunmuştur. FO değişkeni ise ADF ve PP testlerine göre birinci farkı alındığında, KPSS testine göre ise düzey halde durağan bulunmuştur. Durağanlık analizi sonuçları üç birim kök testinin tamamında veya ikisinde alınan sonuçlar çerçevesinde yorumlanmış ve bütün değişkenlerin birinci farkı alınarak kullanılmasına karar verilmiştir.

Tablo 2: Birim Kök Testi Sonuçları

\begin{tabular}{|c|c|c|c|c|c|c|}
\hline \multirow{2}{*}{\multicolumn{2}{|c|}{ Değişkenler }} & \multicolumn{2}{|c|}{ ADF t istatistiği(Düzey) } & \multicolumn{2}{|c|}{ ADF t istatistiği (Birinci Fark) } & \multirow{2}{*}{ Karar } \\
\hline & & Sabit & Sabit+Trend & Sabit & Sabit+Trend & \\
\hline \multirow{2}{*}{\multicolumn{2}{|c|}{ FFO }} & $3.153(4)$ & $1.9928(4)$ & $-2.905(2)$ & $-4.305(3)$ & \multirow{2}{*}{$\mathrm{I}(1)$} \\
\hline & & [1.000] & [1.000] & {$[0.049]^{* *}$} & {$[0.005]^{* * *}$} & \\
\hline \multirow{2}{*}{\multicolumn{2}{|c|}{ SUE }} & $0.486(6)$ & $-3.509(10)$ & $-3.143(5)$ & $-3.196(5)$ & \multirow{2}{*}{$\mathrm{I}(1)$} \\
\hline & & [0.985] & {$[0.045]^{* *}$} & {$[0.027]^{* *}$} & {$[0.092]^{*}$} & \\
\hline \multirow{2}{*}{\multicolumn{2}{|c|}{ YKi }} & $-1.529(5)$ & $-3.753(1)$ & $-6.945(4)$ & $-6.905(4)$ & \multirow{2}{*}{$\mathrm{I}(1)$} \\
\hline & & [0.513] & {$[0.024]^{* *}$} & {$[0.000]^{* * *}$} & {$[0.000]^{* * *}$} & \\
\hline \multirow{2}{*}{\multicolumn{2}{|c|}{ RKFE }} & $1.456(1)$ & $-2.653(1)$ & $-5.098(0)$ & $-5.428(0)$ & \multirow{2}{*}{$\mathrm{I}(1)$} \\
\hline & & [0.999] & {$[0.258]$} & {$[0.000]^{* * *}$} & {$[0.000]^{* * *}$} & \\
\hline \multirow{2}{*}{\multicolumn{2}{|c|}{ FO }} & $-2.388(1)$ & $-2.940(1)$ & $-6.543(0)$ & $-6.503(0)$ & \multirow{2}{*}{$\mathrm{I}(1)$} \\
\hline & & {$[0.148]$} & [0.155] & {$[0.000]^{* * *}$} & {$[0.000]^{* * *}$} & \\
\hline \multirow{2}{*}{\multicolumn{2}{|c|}{ Değişkenler }} & \multicolumn{2}{|c|}{ PP t istatistiği(Düzey) } & \multicolumn{2}{|c|}{ PP t istatistiği (Birinci Fark) } & \multirow{2}{*}{ Karar } \\
\hline & & Sabit & Sabit+Trend & Sabit & Sabit+Trend & \\
\hline \multirow{2}{*}{\multicolumn{2}{|c|}{ FFO }} & $3.707(3)$ & $1.248(2)$ & $-4.970(3)$ & $-6.171(2)$ & \multirow{2}{*}{$\mathrm{I}(1)$} \\
\hline & & [1.000] & [1.000] & {$[0.000]^{* * *}$} & {$[0.000]^{* * *}$} & \\
\hline \multirow{2}{*}{\multicolumn{2}{|c|}{ SUE }} & $0.661(14)$ & $-6.479(5)$ & $-20.845(13)$ & $-21.672(14)$ & \multirow{2}{*}{$\mathrm{I}(1)$} \\
\hline & & [0.9906] & {$[0.0000]^{* * *}$} & {$[0.0001]^{* * *}$} & {$[0.0000]^{* * *}$} & \\
\hline \multirow{2}{*}{\multicolumn{2}{|c|}{ YKi }} & $-4.255(2)$ & $-6.215(3)$ & & & \multirow{2}{*}{$\mathrm{I}(0)$} \\
\hline & & {$[0.001]^{* * *}$} & {$[0.000]^{* * *}$} & & & \\
\hline \multirow{2}{*}{\multicolumn{2}{|c|}{ RKFE }} & $2.024(4)$ & $-2.680(3)$ & $-5.008(1)$ & $-5.377(1)$ & \multirow{2}{*}{$\mathrm{I}(1)$} \\
\hline & & [0.999] & [0.247] & {$[0.000]^{* * *}$} & {$[0.000]^{* * *}$} & \\
\hline \multirow{2}{*}{\multicolumn{2}{|c|}{ FO }} & $-1.612(0)$ & $-2.347(1)$ & $-6.347(5)$ & $-6.301(5)$ & \multirow{2}{*}{$\mathrm{I}(1)$} \\
\hline & & [0.471] & [0.404] & {$[0.000]^{* * *}$} & {$[0.000]^{* * *}$} & \\
\hline \multirow{2}{*}{\multicolumn{2}{|c|}{ Değişkenler }} & KPSS LM & iği(Düzey) & KPSS & atistiği & Karar \\
\hline & & Sabit & Sabit+Trend & Sabit & Sabit+Trend & \\
\hline $\mathrm{FFO}$ & & $0.810(6)$ & $0.280(6)$ & $0.853(5)$ & $0.154(3)^{* * *}$ & $\mathrm{I}(1)$ \\
\hline SUE & & $1.155(7)$ & $0.060(5)^{* * *}$ & $0.233(18)^{* * *}$ & $0.123(19)^{* * *}$ & $\mathrm{I}(1)$ \\
\hline YKi & & $0.903(6)$ & $0.146(5)^{* * *}$ & $0.500(82)^{* * *}$ & $0.500(82)^{* * *}$ & $\mathrm{I}(1)$ \\
\hline RKF & & $1.148(7)$ & $0.299(6)$ & $0.535(5)^{* * *}$ & $0.157(4)^{* * *}$ & $\mathrm{I}(1)$ \\
\hline FO & & $0.574(6)^{* * *}$ & $0.067(6)^{* * *}$ & & & $\mathrm{I}(0)$ \\
\hline & $\% 1$ & 0.7390 & 0.2160 & 0.7390 & 0.2160 & \\
\hline Anlamillik & $\% 5$ & 0.4630 & 0.1460 & 0.4630 & 0.1460 & \\
\hline & $\% 10$ & 0.3470 & 0.1190 & 0.3470 & 0.1190 & \\
\hline
\end{tabular}

Parantez içindeki değerler ADF testinde Akaike Bilgi Kriterine, PP ve KPSS testinde ise Newey-West tahmincisine göre seçilen gecikme uzunluklarını vermektedir. Köşeli parantez içindeki değerler ise olasılık değerlerini vermektedir. Buna göre ** ve *** sırasıyla \%5 ve \%1 anlamlılık düzeylerinde durağanlığı ifade etmektedir. 
Çalışmada ikinci olarak tahmin modeli için en uygun gecikme uzunluğu belirlenmektedir. Tablo 3'te LR (Olabilirlik Oran Testi), FPE (Son Öngörü Hatası), AIC (Akaike Bilgi Kriteri), SC (Schwarz Bilgi Kriteri) ve HQ (Hannan-Quinn Bilgi Kriteri) gibi ölçütlere göre en uygun gecikme uzunlukları gösterilmektedir. Çalışmada aylık frekansta veri kullanıldığı için gecikme uzunluğunun belirlenmesinde 12 gecikmeye kadar olan değerlere yer verilmektedir. Test sonuçlarına göre en uygun gecikme uzunluğu için üç kriterin 1 gecikmeyi göstermesi nedeniyle kullanılan modelde gecikmenin 1 olmasına karar verilmiştir.

Tablo 3: Gecikme Uzunluğu Test Sonuçları

\begin{tabular}{ccccccc}
\hline Gecikme & LogL & LR & FPE & AIC & SC & HQ \\
\hline 0 & 547.9108 & NA & $1.57 \mathrm{e}-13$ & -15.29326 & $-15.13392^{*}$ & -15.22990 \\
1 & 593.1920 & $82.90932^{*}$ & $8.88 \mathrm{e}-14^{*}$ & -15.86456 & -14.90850 & $-15.48437^{*}$ \\
2 & 614.0474 & 35.24850 & $1.01 \mathrm{e}-13$ & -15.74781 & -13.99503 & -15.05079 \\
3 & 632.5573 & 28.67738 & $1.24 \mathrm{e}-13$ & -15.56500 & -13.01550 & -14.55114 \\
4 & 642.3123 & 13.73942 & $2.01 \mathrm{e}-13$ & -15.13556 & -11.78934 & -13.80487 \\
5 & 669.2334 & 34.12531 & $2.08 \mathrm{e}-13$ & -15.18967 & -11.04674 & -13.54216 \\
6 & 690.2473 & 23.67760 & $2.67 \mathrm{e}-13$ & -15.07739 & -10.13773 & -13.11304 \\
7 & 714.2189 & 23.63399 & $3.36 \mathrm{e}-13$ & -15.04842 & -9.312048 & -12.76725 \\
8 & 752.0265 & 31.95011 & $3.15 \mathrm{e}-13$ & -15.40920 & -8.876108 & -12.81120 \\
9 & 785.8316 & 23.80638 & $3.76 \mathrm{e}-13$ & -15.65723 & -8.327419 & -12.74240 \\
10 & 812.8131 & 15.20086 & $6.62 \mathrm{e}-13$ & -15.71305 & -7.586519 & -12.48138 \\
11 & 855.4774 & 18.02715 & $1.02 \mathrm{e}-12$ & -16.21063 & -7.287386 & -12.66214 \\
12 & 950.6229 & 26.80155 & $6.47 \mathrm{e}-13$ & $-18.18656 *$ & -8.466597 & -14.32124 \\
\hline
\end{tabular}

* ölçütlere göre belirlenen en uygun gecikme seviyesini göstermektedir.

Çalışmada bu aşamada tahmin edilen modelin güvenilirliğine ilişkin test sonuçlarına yer verilmektedir. Illk olarak otokorelasyon sorununun varlığı incelenmiştir. Tablo 4'te yer alan LM testi sonuçlarına göre gecikme uzunluğu 1 olarak belirlenen modelde olasılık değerinin 0.05 ten büyük olduğu dolayısıyla otokorelasyon olmadığını ifade eden temel hipotezin reddedilemediği görülmektedir. Dolayısıyla otokorelasyon sorunun olmadığı sonucuna ulaşılmaktadır.

Tablo 4: Otokorelasyon LM Testi Sonuçları

\begin{tabular}{ccc}
\hline Gecikme & LM ístatistiği & Olasılık \\
\hline 1 & 29.91926 & 0.2273 \\
2 & 31.89438 & 0.1611 \\
3 & 32.31976 & 0.1490 \\
4 & 21.29498 & 0.6761 \\
5 & 22.31642 & 0.6174 \\
6 & 30.41599 & 0.2091 \\
7 & 33.21632 & 0.1257 \\
8 & 20.17346 & 0.7377 \\
\hline
\end{tabular}

Şekil 2'de yer alan grafikten AR Karakteristik Polinomunun Ters Kökleri görülmektedir. Bütün köklerin çemberin içinde yer almasından hareketle modelin durağan olduğunu ve modelin istikrarlı bir yapı gösterdiği ifade edilebilir. 
Şekil 2: AR Karakteristik Polinomunun Ters Kökleri

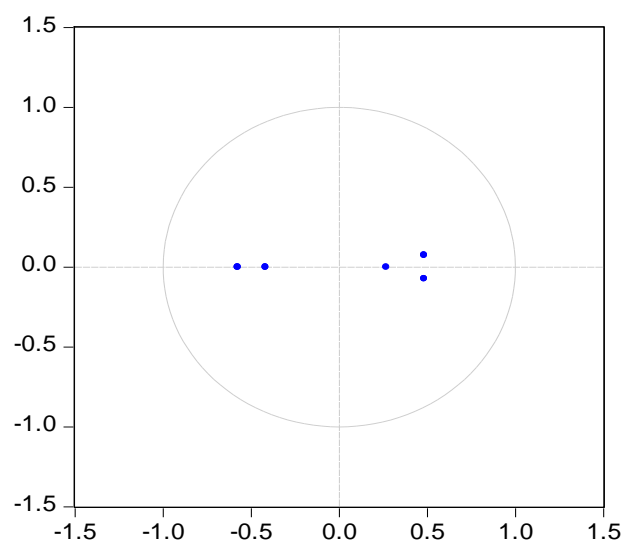

Son olarak değişen varyans sorununun varlığı araştırılmaktadır. Tablo 5 'te White testi sonuçları yer almaktadır. Test sonucuna göre ki-kare değeri 338 çıkan modelde $\% 5$ anlamlılık düzeyinde hata terimlerinin varyansının bütün örneklem için sabit olduğunu ifade eden boş hipotez reddedilememekte ve değişen varyans sorununun bulunmadığı sonucuna ulaşılmaktadır.

Tablo 5: White Testi Sonuçları

\begin{tabular}{ccc}
\hline \multicolumn{1}{ll}{ Joint test } & & \\
\hline Ki Kare & Serbestlik Derecesi & Olasılık \\
\hline 338.6 & 300 & 0.06 \\
\hline
\end{tabular}

Yapısal VAR modeli konulan kısıtlamalar ve belirlenen gecikme uzunluğunda tahmin edildikten sonra değişkenler arasındaki ilişkiyi yorumlamak için etki tepki fonksiyonları ve varyans ayrıştırma analizi sonuçları elde edilmektedir. Şekil 3'de reel konut fiyatlarının modeldeki değişkenlerde ortaya çıkan bir standart sapmalık şoka verdiği tepkiyi gösteren grafikler yer almaktadır. İlk grafik reel konut fiyatlarının federal fon oranındaki bir standart sapmalık şoka tepkisini göstermektedir. Buna göre federal fon oranlarındaki pozitif bir şok başka bir deyişle FED'in daraltıcı para politikasına konut fiyatlarının ilk dönemde negatif bir tepki verdiği, ikinci dönemden itibaren tepkinin pozitife döndüğü ve sekizinci dönemden itibaren ortadan kalktığı görülmektedir. Böylelikle, FED'in daraltıcı para politikasının konut fiyatları üzerinde yalnızca ilk dönemde negatif bir şok etkisi oluşturduğunu ifade edebiliriz. İkinci grafik reel konut fiyatlarının sanayi üretim endeksindeki bir standart sapmalık şoka tepkisini göstermektedir. Buna göre sanayi üretim endeksindeki pozitif bir şok reel konut fiyatlarında çok küçük negatif bir tepki görmekte ve üçüncü dönemden sonra tepki ortadan kalkmaktadır. Üçüncü grafik reel konut fiyatlarının yapı kullanım izni sayısındaki bir standart sapmalık şoka tepkisini göstermektedir. Buna göre yapı kullanım izni sayısındaki pozitif bir şok beklentilerin aksine reel konut fiyatlarında ilk iki dönemde geçici pozitif bir tepki ortaya çıkarmaktadır. Dördüncü grafikte reel konut fiyatlarının kendisine gösterdiği tepkiye bakıldığında, reel konut fiyatlarında ortaya çıkan pozitif bir şok ilk dönemden itibaren pozitif bir tepki ortaya çıkarmakta ve bu tepki sonraki dönemlerde azalarak devam etmektedir. Yedinci dönemden sonra ise şokun etkisi ortadan kalkmaktadır. Son grafik, reel konut fiyatlarının gecelik faiz oranındaki bir standart sapmalık şoka tepkisini göstermektedir. Buna göre, Türkiye ekonomisinde uygulanan daraltıcı para politikası diğer bir ifadeyle gecelik faiz 
oranlarındaki pozitif bir şok reel konut fiyatlarında ilk dönemde güçlü negatif bir tepki ortaya çıkarmaktadır. Bu tepki dört dönem daha azalarak devam etmekte ve beşinci dönemde ortadan kalkmaktadır. Sonuçlar istatistiksel anlamlılıkları açısından değerlendirildiğinde, yalnızca konut fiyatlarının kendi gecikmeli değerlerine verdiğine ilişkin sonucun 4 dönem boyunca anlamlı olduğu görülmektedir. Buna göre, ilgili dönemde para politikasının konut fiyatları üzerinde etkisiz olduğu ve konut fiyatlarının tepki verdiği değişkenin yalnızca kendi gecikmeli değerleri olduğu ifade edilebilir.

\section{Şekil 3: Etki Tepki Fonksiyonları (Reel Konut Fiyatlarının Tepkisi)}

Response to Structural One S.D. Innovations \pm 2 S.E.
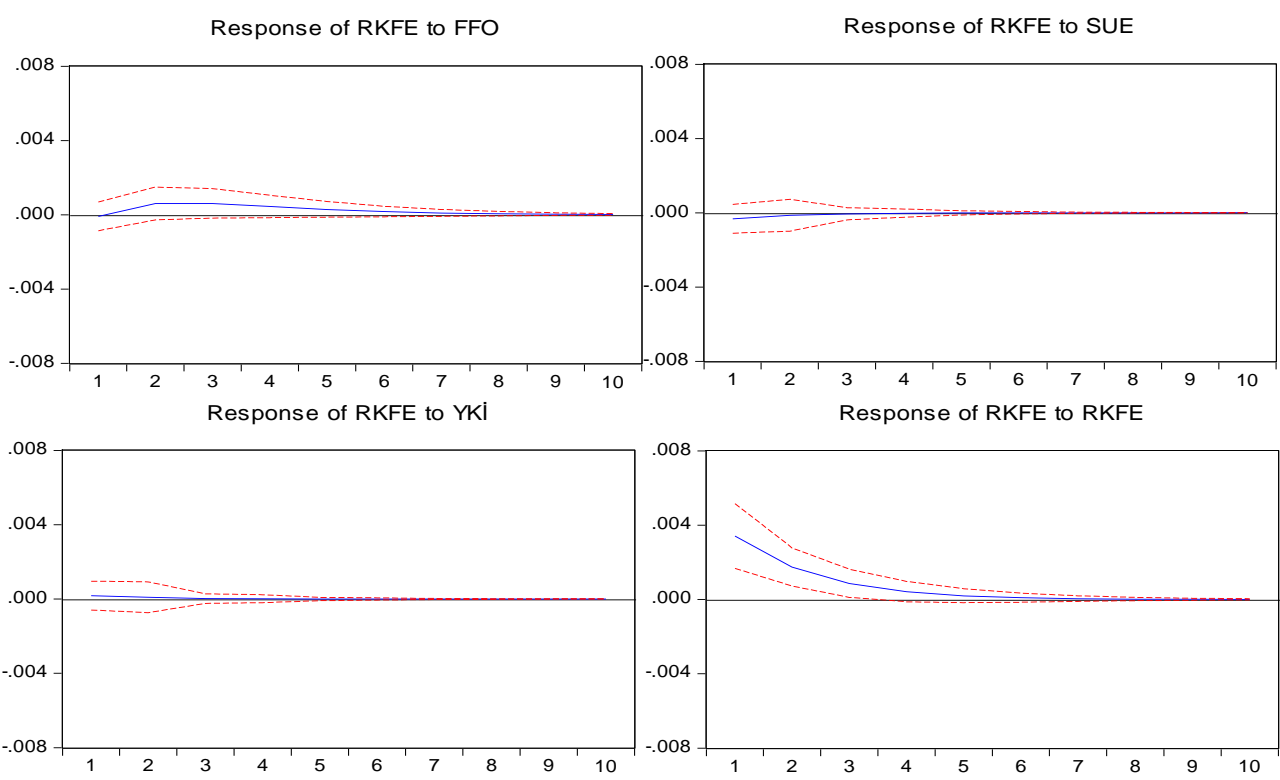

Response of RKFE to FO

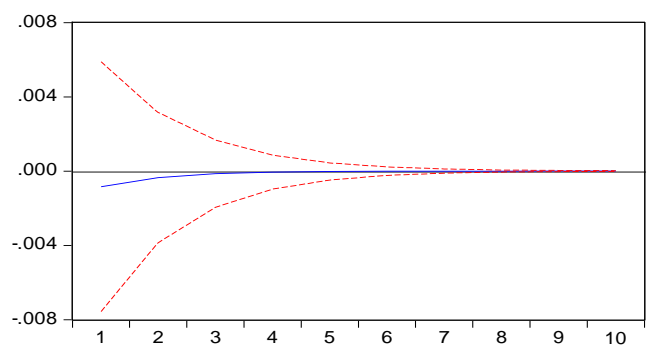

Literatürde para politikası ve konut fiyatları ilişkisini araştıran çalışmalarda üzerinde durulan başka bir husus konut fiyatlarında ortaya çıkan değişime diğer değişkenlerin verdiği tepkidir. Şekil 4'te sanayi üretim endeksi, yapı kullanım izni sayısı ve gecelik faiz oranlarının reel konut fiyatlarında ortaya çıkan bir standart sapmalık şoka verdiği tepkiyi gösteren grafikler yer almaktadır. İlk grafik sanayi üretim endeksinin reel konut fiyatlarındaki bir standart sapmalık şoka tepkisini göstermektedir. Buna göre sanayi üretim endeksinin reel konut fiyatlarındaki değişime herhangi bir tepki vermediği görülmektedir. İkinci grafikte, yapı kullanım izni sayısının reel konut fiyatlarındaki bir standart sapmalık şoka tepkisini 
göstermektedir. Buna göre reel konut fiyatlarındaki pozitif bir şoka yapı kullanım izni sayısı gecikmeli olarak ikinci dönemde pozitif bir tepki vermektedir. Tepki sonraki dönemlerde dengeye yönelmekte ve sekizinci dönemden sonra ortadan kalkmaktadır. Üçüncü grafik gecelik faiz oranlarının reel konut fiyatlarındaki bir standart sapmalık şoka tepkisini göstermektedir. Buna göre, reel konut fiyatlarındaki pozitif bir şoka gecelik faiz oranlarının yalnızca ilk dönemde pozitif bir tepki verdiği görülmektedir. Bu sonuçlar istatistiki açıdan ise anlamsızdır. Buradan hareketle, merkez bankasının konut fiyatlarını göz önünde bulundurmadan politika ayarlamalarına gittiğini göstermektedir.

Şekil 4: Etki Tepki Fonksiyonları (Reel Konut Fiyatı Şoklarına Diğer Değişkenlerin Tepkisi)

Response to Structural One S.D. Innovations \pm 2 S.E.
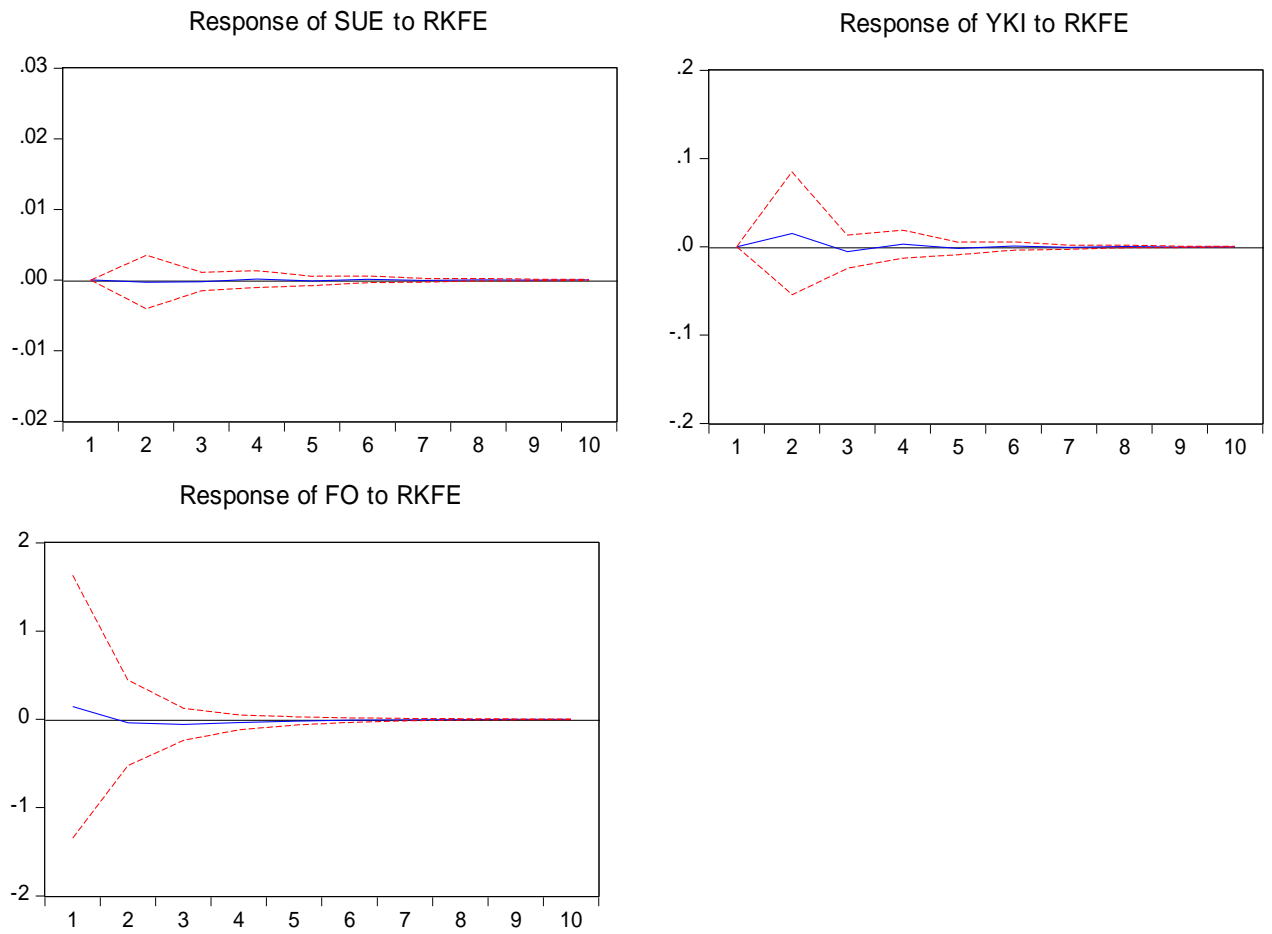

Varyans ayrıştırması analizi ise modelde yer alan değişkenlerde ortaya çıkan değişimin diğer değişkenler tarafından ne oranda açıklandığını göstermektedir. Aşağıda tablo 6 reel konut fiyatları değişkeninin varyans ayrıştırma analizi sonucunu vermektedir. Tabloda yer alan her bir sütun reel konut fiyatlarının öngörü hata varyansının diğer değişkenler tarafından ne oranda açıklandığını ifade etmektedir. Tablodan hareketle reel konut fiyatlarındaki değişimin ilk ayda yüzde 93.1 oranında kendinden, yüzde 6.9 oranında diğer değişkenlerden kaynaklandığı ifade edilebilir. Burada en büyük pay yüzde 5.6 oranında ülke içi faiz oranlarına aittir. Sonraki aylarda federal fon oranının etkisi artmakta ve onuncu ayda yüzde 5.96'ya ulaşmaktadır. Faiz oranlarının açıklayıcılık gücü ise onuncu ayda yüzde 4.7'ye gerilemektedir. Netice itibariyle, reel konut fiyatlarındaki değişimlerde kendinden sonra en çok ülke içi faiz oranları ve federal fon oranı etkili bulunmuştur. Sanayi üretim endeksi ve yapı kullanım izni değişkenleri ise oldukça küçük etkiye sahiptir. 
Tablo 6: RKFE'nin Varyans Ayrıştırma Analizi Sonuçları

\begin{tabular}{ccccccc}
\hline Dönem & S.E. & FFO & SUE & YKi & RKFE & FO \\
\hline 1 & 0.003536 & 0.070642 & 0.854635 & 0.256790 & 93.19734 & 5.620597 \\
2 & 0.004007 & 2.328518 & 0.788626 & 0.249921 & 91.48146 & 5.151478 \\
3 & 0.004147 & 4.312052 & 0.758267 & 0.235538 & 89.76707 & 4.927079 \\
4 & 0.004192 & 5.338144 & 0.745863 & 0.231137 & 88.84273 & 4.842124 \\
5 & 0.004206 & 5.754559 & 0.741562 & 0.229600 & 88.46208 & 4.812196 \\
6 & 0.004210 & 5.901666 & 0.740142 & 0.229131 & 88.32632 & 4.802736 \\
7 & 0.004211 & 5.948412 & 0.739722 & 0.229018 & 88.28293 & 4.799914 \\
8 & 0.004212 & 5.962231 & 0.739602 & 0.228983 & 88.27006 & 4.799127 \\
9 & 0.004212 & 5.966050 & 0.739570 & 0.228977 & 88.26649 & 4.798918 \\
10 & 0.004212 & 5.967055 & 0.739561 & 0.228975 & 88.26554 & 4.798865 \\
\hline
\end{tabular}

Tablo 7 para politikası göstergesi olarak modele dâhil ettiğimiz BIST bankalar arası para piyasası gecelik faiz oranlarının varyans ayrıştırma analizi sonucunu vermektedir. Sonuçlardan hareketle para politikası değişimlerinin reel konut fiyatları ve diğer değişkenler tarafından ne oranda açıklandığına ilişkin çıkarımda bulunulabilmektedir. Buna göre, faiz oranlarındaki değişimin ilk ayda yüzde 91.5 oranında kendinden, yüzde 3.3 reel konut fiyatları, yüzde 3.5 sanayi üretim endeksi, yüzde 1.1 federal fon oranından kaynaklandığı görülmektedir. Sonraki aylarda kendi açıklayıcılık gücü düşen faiz oranlarında sanayi üretim endeksinin etkisi artmakta ve onuncu ayda yüzde 6.4'e ulaşmaktadır. Buradan hareketle, faiz oranlarında ortaya çıkan değişimde kendinden sonra en önemli değişkenler sanayi üretim endeksi, reel konut fiyatları ve federal fon oranıdır.

Tablo 7: FO'nun Varyans Ayrıştırma Analizi Sonuçları

\begin{tabular}{|c|c|c|c|c|c|c|}
\hline Dönem & S.E. & FFO & SUE & YKi & RKFE & $\mathrm{FO}$ \\
\hline 1 & 0.785074 & 1.151181 & 3.505599 & 0.397569 & 3.352169 & 91.59348 \\
\hline 2 & 0.834133 & 1.040577 & 6.462239 & 0.421533 & 3.206868 & 88.86878 \\
\hline 3 & 0.838799 & 1.049925 & 6.392005 & 0.417945 & 3.647029 & 88.49310 \\
\hline 4 & 0.840385 & 1.105168 & 6.433644 & 0.416519 & 3.822471 & 88.22220 \\
\hline 5 & 0.840842 & 1.145032 & 6.428114 & 0.417701 & 3.874769 & 88.13438 \\
\hline 6 & 0.841003 & 1.164344 & 6.427744 & 0.418132 & 3.888659 & 88.10112 \\
\hline 7 & 0.841053 & 1.172268 & 6.427117 & 0.418394 & 3.891390 & 88.09083 \\
\hline 8 & 0.841069 & 1.174891 & 6.426970 & 0.418518 & 3.892060 & 88.08756 \\
\hline 9 & 0.841073 & 1.175767 & 6.426913 & 0.418556 & 3.892145 & 88.08662 \\
\hline 10 & 0.841074 & 1.176007 & 6.426898 & 0.418576 & 3.892167 & 88.08635 \\
\hline
\end{tabular}

Nihai olarak, etki tepki fonksiyonu sonuçları para politikası, konut sektöründe kullanım izni alınan konut sayısı ve ABD para politikasının konut fiyatları üzerinde istatistiksel açıdan anlamlı bir etkisi olmadığını göstermiştir. Bununla birlikte, konut fiyatlarının kendi gecikmeli değerlerinden istatistiksel açıdan anlamlı bir şekilde pozitif olarak etkilendiği sonucu elde edilmiştir. Varyans ayrıştırma analizi sonuçları ise konut fiyatlarındaki değişimin büyük oranda kendisi, ülke ve ABD faiz oranı tarafından açıklandığını göstermiştir.

\section{Sonuç}

2008 finansal krizinin nedenlerinin başında Amerikan konut piyasalarında yaşanan fiyat balonunun sayılması konut sektöründeki gelişmelere yönelik ilgiyi artırmıştır. Bu dönemde ortaya çıkan fiyat balonunu 2000'li yılların başından itibaren uygulanan genişletici para politikasıyla ilişkilendiren bulguların ortaya konulması, para politikası ve konut fiyatları arasındaki ilişkinin diğer ülkeler açısından da incelenmesine neden olmuştur. Merkez bankalarının temel hedefi pek çok ülkede fiyat istikrarı olarak belirlenmiştir. Bu nedenle doğrudan konut fiyatlarının seçildiği özel hedeflemelerin yapılması mümkün görünmemektedir. Bununla birlikte, finansal krizin $A B D$ ekonomisi ve küresel ekonomide 
ortaya çıkardığı ekonomik tahribat Merkez bankalarını konut fiyatlarını izlemek ve fiyat düzeyi üzerinde ortaya çıkabilecek muhtemel istikrarsızlıklara karşı önlem almak zorunda bırakmıştır.

Çalışmanın amacı Türkiye ekonomisinde para politikası ve konut fiyatları arasındaki ilişkinin ampirik olarak araştırılmasıdır. Bu doğrultuda ampirik analiz yöntemi olarak Yapısal VAR analizi tercih edilmektedir. Bu noktada çalışmanın gerek Türkiye ekonomisini incelemesi gerekse kullanılan yöntem itibariyle çok fazla çalışmanın bulunmadığı literatüre katkı sağlaması amaçlanmıştır. Yapısal VAR yönteminin temel özelliği, standart VAR analizinden farklı olarak iktisat teorisi ve diğer ön bilgilerden hareketle modeldeki eşzamanlı etkilerden bazılarının kısıtlanarak teoriyle uyumlu yapısal şokların oluşmasına imkân vermesidir. Çalışmanın modeli; federal fon oranı, sanayi üretim endeksi, yapı kullanım izni, reel konut fiyat endeksi ve BIST bankalar arası para piyasası gecelik faiz oranı değişkenlerinden oluşmaktadır. Analiz 2011:1-2017:12 dönemini kapsamakta ve analizde aylık veriler kullanılmaktadır.

Çalışmanın etki tepki analizi sonuçlarına göre, uygulanan daraltıcı para politikası diğer bir ifadeyle gecelik faiz oranlarındaki pozitif bir şok reel konut fiyatlarında ilk dönemde güçlü negatif bir tepki ortaya çıkarmaktadır. Bu tepki beşinci dönemde ortadan kalkmaktadır. Modeldeki diğer değişkenlerden federal fon oranındaki pozitif bir şoka başka bir deyişle FED'in daraltıcı para politikasına konut fiyatlarının ilk dönemde negatif bir tepki verdiği görülmektedir. Sonraki dönemlerde etki pozitife dönüp dengeye yönelmektedir. Para politikası ve $A B D$ para politikasının konut fiyatları üzerindeki etkileri istatistiksel açıdan anlamlı değildir. Bu nedenle, para politikası ve ABD para politikasının konut fiyatları üzerinde etkisinin olmadığı ifade edilebilir. Son olarak reel konut fiyatlarının kendisine gösterdiği tepkiye bakıldığında, reel konut fiyatlarında ortaya çıkan pozitif bir şokun etkisinin pozitif ve diğer değişkenlere göre daha kalıcı olduğu görülmektedir. Bu etki istatiksel açıdan da anlamlıdır. Varyans ayrıştırması analizi sonuçlarına göre ise, reel konut fiyatlarındaki değişimin ilk ayda yüzde 93.1 oranında kendinden, yüzde 6.9 oranında diğer değişkenlerden kaynaklandığı ifade edilebilir. Burada en büyük pay yüzde 5.6 oranında faiz oranlarına aittir. Sonraki aylarda federal fon oranının etkisi artmakta ve onuncu ayda yüzde 5.96'ya ulaşmaktadır. Netice itibariyle, reel konut fiyatlarındaki değişimler kendinden sonra en çok faiz oranları ve federal fon oranı tarafından açıklanmaktadır. Modele para politikası göstergesi olarak dâhil edilen gecelik faiz oranlarının varyans ayrıştırma analizi sonuçları ise, faiz oranlarındaki değişimin ilk ayda yüzde 91.5 oranında kendinden, yüzde 3.3 reel konut fiyatları, yüzde 3.5 sanayi üretim endeksi, yüzde 1.1 federal fon oranından kaynaklandığını göstermiştir. Sonraki aylarda kendi açıklayıcılık gücü düşen faiz oranlarında sanayi üretim endeksinin etkisi artmakta ve onuncu ayda yüzde 6.4'e ulaşmaktadır. Bu çerçevede, faiz oranlarında ortaya çıkan değişimde kendinden sonra en önemli açıklayıcı değişkenler sanayi üretim endeksi, reel konut fiyatları ve federal fon oranıdır.

Konut sektörü yapısı itibariyle ekonomideki pek çok sektörle bağlantı içinde olan bir özelliğe sahiptir. Gelişmiş ülkelerde 2008 finansal kriziyle birlikte yaşanmış olan olumsuz tecrübeler sektörün yakından takip edilmesi gerektiğini ortaya koymuştur. Çalışmada elde edilen ampirik sonuçlar itibariyle, para politikası ve konut fiyatları arasında bir ilişki olmadığı görülmektedir. Bununla birlikte, konut fiyatlarına ilişkin verilerin yayımlanmasına 2010 yılında başlanması nedeniyle analizde kullanılan dönemin kısa bir dönemi kapsaması çalışmanın sınırıı̆̆ını oluşturmaktadır. Dolayısıyla, daha geniş bir dönemin analiz edilmesi daha güvenilir sonuçlar elde edilmesini sağlayacaktır. 


\section{Kaynaklar}

Akkas, Murat Engin; Sayılgan Güven (2015), "Konut Fiyatlari ve Konut Kredisi Faizi : Toda-Yamamoto Nedensellik Testi", 19. Finans Sempozyumu kitabı içinde, 367-78. Çorum: Finans Bilim Platformu.

Alper, Koray; Tiryaki, S. Tolga (2011), "Zorunlu Karşılıkların Para Politikasındaki Yeri”, TCMB Ekonomi Notları, Sayı: 2011-08. http://www.tcmb.gov.tr/wps/wcm/connect/c3bf7fab-73b6-42f2-b2e1888897ef563b/EN1108eng.pdf?MOD=AJPERES\&CACHEID=ROOTWORKSPACE-c3bf7fab-73b6-42f2-b2e1888897ef563b-m3fw4-w, (Erişim:03.07.2018).

Ando, Albert; Modigliani, Franco (1963), "The "Life-Cycle" Hypothesis of Saving: Aggregate Implications and Tests", American Economic Review, 53, 55-84.

Badurlar, İlkay Öner (2008), "Türkiye'deki Konut Fiyatları Ille Makro Ekonomik Değişkenler Arasındaki İlişkinin Araştırılması", Anadolu Üniversitesi Sosyal Bilimler Dergisi, Cilt. 8, No. 1, 223-38.

Bekmez, Selahattin; Özpolat, Aslı (2013), “Türkiye'de Konut Talebinin Belirleyenleri: Dinamik Bir Analiz”, Tisk Akademi Sayı. 2: 171-87.

Bernanke, Ben S; Gertler Mark (1995), "Inside the Black Box: The Credit Channel of Monetary Policy Transmission", The Journal of Economic Perspectives, Vol. 9, No. 4, 27-48.

Bjørnland, Hilde C.; Jacobsen, Dag Henning (2010), "The Role of House Prices in the Monetary Policy Transmission Mechanism in Small Open Economies", Journal of Financial Stability Vol. 6, No. 4: 218-29. https://doi.org/10.1016/j.jfs.2010.02.001.

Boivin, Jean; Kiley, Michael T.; Mishkin, Frederic S (2010), "How has the Monetary Transmission Mechanism Evolved over Time?”, NBER Working Paper Series, No. 15879.

Clarida, Richard; Galí, Jordi; Gertler, Mark (2001), “Optimal Monetary Policy in Open versus Closed Economies: An Integrated Approach", American Economic Review, Vol. 91, No. 2: 248-52.

Darıcı, Burak (2018), "Para Politikası ve Konut Fiyatları ilişkisi: Türkiye Ekonomisi İçin Ampirik Bir Analiz”, Anemon Muş Alparslan Üniversitesi Sosyal Bilimler Dergisi, 6(ICEESS'18), 221-228.

Dokko, Jane vd. (2009), "Monetary Policy and the Housing Bubble", Finance and Economics Discussion Series, No. 2009-49, Washington.

Elbourne, Adam (2008), "The UK Housing Market and the Monetary Policy Transmission Mechanism: An SVAR Approach", Journal of Housing Economics, Vol. 17, No. 1: 65-87. https://doi.org/10.1016/j.jhe.2007.09.002.

https://www.stlouisfed.org/, (Erişim Tarihi:10.08.2018).

http://evds.tcmb.gov.tr/, (Erişim Tarihi: 10.08.2018).

http://www.tuik.gov.tr, (Erişim Tarihi: 10.08.2018).

Giuliodori, Massimo (2005), "The Role of House Prices in the Monetary Transmission Mechanism across European Countries", Scottish Journal of Political Economy, Vo. 52, No. 4: 519-43. https://doi.org/10.1111/j.14679485.2005.00354.x.

Goodhart, Charles; Hofmann, Boris (2008), "House Prices, Money, Credit and the Macroeconomy”, European Central Bank Working Paper Series, No. 888.

Guo, Feng; Huang, Ying Sophie (2010), “Does 'Hot Money' Drive China's Real Estate and Stock Markets?”, International Review of Economics and Finance, Vol. 19, No. (3): 452-66. https://doi.org/10.1016/j.iref.2009.10.014.

lacoviello, Matteo (2002), "House Prices and Business Cycles in Europe: a VAR Analysis", Boston College Working Papers in Economics, No. 540.

İslamoğlu, Bahar; Buluş, Abdulkadir (2018), “Mortgage Piyasası ve Para Politikasının Konut Fiyatlarına Etkisi: Türkiye Üzerine Bir Uygulama”, Süleyman Demirel Üniversitesi Iktisadi ve Idari Bilimler Fakültesi Dergisi, Cilt. 23, Sayı 2, 455-66.

Jarocinski, Marek; Frank Smets (2008), "House Prices and the Stance of Monetary Policy", European Central Bank Working Paper Series, No. 891.

Kara, Hakan (2012), “Küresel Kriz Sonrası Para Politikası”, TCMB Çalışma Tebliği, Sayı. 2012/17.

Karamelikli, Hüseyin (2016), "Linear and Nonlinear Dynamics of Housing Price in Turkey". Ekonomia, Vol. 46, No. 46, 81-98. https://doi.org/10.17451/eko/46/2016/238.

Kasai, Ndahiriwe; Gupta, Rangan (2010), "Financial Liberalisation and the Effectiveness of Monetary Policy on House Prices in South Africa", The IUP Journal of Monetary Economics, Vol. 8, No. 4: 59-74.

Kim, Soyoung; Roubini, Nouriel (2000), "Exchange Rate Anomalies in the Industrial Countries: A Solution with a 


\section{Eskişehir Osmangazi Üniversitesi ïiBF Dergisi}

Structural VAR Approach", Journal of Monetary Economics, Vol. 45, No. 3: 561-86. https://doi.org/10.1016/S0304-3932(00)00010-6.

Kolcu, Fatma; Yamak, Nebiye (2018), "Gelir ve Faiz Oranlarinin Konut Fiyatları Üzerindeki Kisa ve Uzun Dönem Etkileri", Uluslararası iktisadi ve idari incelemeler Dergisi, Prof. Dr. Harun Terzi Özel Sayısı. 141-52. https://doi.org/10.18092/ulikidince.439535.

Leamer, Edward (2007), “Housing IS the Business Cycle", NBER Working Paper Series, No. 13428. https://doi.org/10.3386/w13428.

McDonald, John F.; Stokes, Houston H. (2013), "Monetary Policy, Mortgage Rates and Housing Bubble". Economics \& Finance Research No. 1: 82-91. https://doi.org/http://dx.doi.org/10.1080/21649480.2013.870490.

Mishkin, Frederic S. (2007), "Housing and the Monetary Transmission Mechanism", NBER Working Paper Series, No. 13518

Musso, Alberto; Neri, Stefano; Stracca, Livio (2011), “Housing, Consumption and Monetary Policy: How Different are the US and the Euro Area?" Journal of Banking and Finance, Vo. 35, No. 11: 3019-41. https://doi.org/10.1016/j.jbankfin.2011.04.004.

Mutsvunguma, Priscilla Tatenda (2013), "Monetary Policy Transmission and House Prices, a VAR Approach . A Case Study of South Africa ( 1994 to 2011 )", Master Thesis, University of the Witwatersrand, Johannesburg.

Öztürk, Nurettin; Fitöz, Esra (2009), "Türkiye'de Konut Piyasasının Belirleyicileri: Ampirik Bir Uygulama”. ZKÜ Sosyal Bilimler Dergisi, Cilt. 5, Sayı. 10: 21-46.

Panagiotidis, Theodore; Printzis, Panagiotis (2016), “On the Macroeconomic Determinants of the Housing Market in Greece: a VECM Approach", International Economics and Economic Policy, Vol. 13, No. 3: 387-409. https://doi.org/10.1007/s10368-016-0345-3.

Pfaff, Bernhard (2008), "VAR, SVAR and SVEC Models: Implementation Within R Package Vars". Journal of Statistical Software, Vol. 27, No. 4. https://doi.org/10.18637/jss.v027.i04.

Rosenberg, Signe (2018), "The Effects of Conventional and Unconventional Monetary Policy on House Prices in the Scandinavian Countries", TUT Economic Research Series, No. 2018/2.

Shi, Song; Jou, Jyh Bang; Tripe, David (2014), "Can Interest Rates Really Control House Prices? Effectiveness and Implications for Macroprudential Policy", Journal of Banking and Finance, Vol. 47, No. 1: 15-28. https://doi.org/10.1016/j.jbankfin.2014.06.012.

Shiller, Robert (2006), "Long-Term Perspectives on the Current Boom in Home Prices". Economists' Voice, Vol. 3, No. 4.

Sims, Christopher A.; Zha, Tao (2006), "Does Monetary Policy Generate Recessions?”, Macroeconomic Dynamics Vol. 10, No. 02: 231-72. https://ideas.repec.org/a/cup/macdyn/v10y2006i02p231-272_05.html.

Stock, James H.; Watson, Mark W. (2003), "Forecasting Output and Inflation: The Role of Asset Prices", Journal of Economic Literature, Vol. XLI: 788-829. https://www.princeton.edu/ mwatson/papers/Stock_Watson_JEL_2003.pdf. (Erişim Tarihi:07.08.2018).

Svensson, Lars E. O. (1998), “Open-Economy Inflation Targeting”, NBER Working Paper Series, No. 6545.

Taylor, John B. (2007), "Housing and Monetary Policy”, NBER Working Paper Series, No. 13682.

Tse, Chin Bun; Timothy Rodgers; Niklewski, Jacek (2014), "The 2007 Financial Crisis and the UK Residential Housing Market: Did the Relationship between Interest Rates and House Prices Change?", Economic Modelling, No. 37: 518-30. https://doi.org/10.1016/j.econmod.2013.08.013.

Uysal, Doğan; Yiğit, Mehmet (2016), "Türkiye'de Konut Talebinin Belirleyicileri (1970-2015): Ampirik Bir Çalışma", Selçuk Üniversitesi Sosyal Bilimler Meslek Yüksekokulu Dergisi, Cilt. 19, Sayı. 1: 185-209.

Wadud, I. K. M.Mokhtarul; Bashar, Omar H.M.N.; Ahmed, Huson Joher Ali (2012), "Monetary Policy and the Housing Market in Australia". Journal of Policy Modeling, Vol. 34, Sayı. 6: 849-63. https://doi.org/10.1016/j.jpolmod.2012.06.002.

Xu, Xiaoqing Eleanor; Chen, Tao (2012), "The Effect of Monetary Policy on Real Estate Price Growth in China", Pacific Basin Finance Journal, Vol. 20, No. 1: 62-77. https://doi.org/10.1016/j.pacfin.2011.08.001.

Yılmaz, Durmuş (2009), “Küresel Kriz ve Merkez Bankası”, TCMB Başkan Konuşmaları, İstanbul. http://www.tcmb.gov.tr/wps/wcm/connect/3c5432cb-b1f3-4f01-8752d0437bddaa4d/Baskan_finans_klup.pdf?MOD=AJPERES\&CACHEID=ROOTWORKSPACE-3c5432cb-b1f3-4f018752-d0437bddaa4d-m3fC4Gd. (Erişim Tarihi: 07.08.2018).

Zhang, Chengsi (2013), "Money, Housing, and Inflation in China”, Journal of Policy Modeling, Vol. 35, No. 1: $75-87$. https://doi.org/10.1016/j.jpolmod.2012.04.006. 